\title{
Essential Characteristics of EFL Practicum Supervisors from Their Perspective
}

\author{
Maysoon A. Dakhiel \\ Faculty of Education, Jeddah University, Saudi Arabia
}

Copyright $(2017$ by authors, all rights reserved. Authors agree that this article remains permanently open access under the terms of the Creative Commons Attribution License 4.0 International License

\begin{abstract}
The present study aims to identify the essential characteristics required for the EFL practicum supervisors from their perspective. The questionnaire validity and reliability was tested through application to a sample of (7) supervisors. Then the questionnaire was distributed to the participants, which consisted of (20) EFL supervisors for the practicum of the EFL student teachers. The results were processed statistically and showed that there is an agreement among the participants in determining the importance of all essential characteristics required for the practicum supervisors. Moreover, there are no statistically significant differences of the perspective of the participants due to the academic qualification, its type and number of years of experience. The study recommended that the essential characteristics required for the practicum supervisors should be a prerequisite for choosing supervisor from the English Language Department, training courses should be held for the supervisors in order to raise their efficiency, and a special guide for the practicum supervisors should be developed.
\end{abstract}

Keywords Essential Characteristics, EFL Practicum Supervisors

\section{Introduction}

It is a well-established fact that the English language has become the major communication tool during the last and present centuries. Thus, it comes as no surprise that the learning and teaching of this language has taken a major position in the educational field. Numerous studies have been conducted to investigate almost every aspect of EFL (English as a Foreign Language)/ESL (English as a Second Language) learning and teaching and a large amount is dedicated to EFL teacher perpetration programs. One of such programs is the "practicum" in which student teachers are subjected to real life teaching experiences. Whereas they were only subjected to theories, in practicum they are given the opportunities to apply these theories into practice $[1][2][3][4][5]$. The field of education occupies a prominent place in the teacher training program, where the educational experience is necessary and essential in the preparation of future teachers. Accordingly, student teachers undergo realistic and practical experiences[6]. Practicum requires the supervision by the program professors or members of the school teaching staff. As supervisors, they have a significant role in managing the student teachers training and providing them with the necessary skills to fulfill their role [7]. Thus, the supervisor must have a number of personal characteristics, solid educational background, and subject matter knowledge. Waite [8] stressed the importance of experience, skills, knowledge, and dispositions for supervisors. Furthermore, Solliday \& Anderson [9] presented the considerations to be taken when assessing supervisors such as personal characteristics, the ability to teach, and the development of teacher education programs. Simmons [10] also pointed to the importance of job satisfaction, teaching experience, and personal characteristics.

As a faculty member at the Curriculum and Instruction Department in the College of Education of King Abdul Aziz University, and having taught EFL teaching methods, and supervised student teachers during the practicum phase of their educational training program, the author has perceived the importance of the necessary characteristics needed for supervisors and the importance of this role. Yet, she has also noticed that the program produces weak EFL teachers. Since numerous studies have been conducted on the subject of teaching methods and educational technology, the author has decided to study supervisors in order to find out what are the main characteristics of good supervision from their point of view. If they can identify them, the problem might lie in the application. Therefore, further research should be conducted to study this aspect. The scarcity of studies dedicated to the characteristics of supervisors from their point of view has also motivated the author to conduct the study.

\section{Statement of the Problem}

What are the necessary characteristics of the practicum 
supervisors at the English Language Department in the College of Education for girls at King Abdul-Aziz University from their perspectives?

This gives rise to the following minor questions:

1. What are the most important characteristics for the practicum supervisors in the English Language Department?

2. What are the least important characteristics for the practicum supervisors in the English Language Department?

3. Are there statistical significances in the necessary characteristics for the practicum supervisors in the English Language Department in accordance with the academic qualification and teaching experience?

\section{Objectives}

The current study attempts to identify:

1. The most important characteristics for the practicum supervisors in the English Language Department.

2. The least important characteristics for the practicum supervisors in the English Language Department.

3. Differences in the necessary characteristics for the practicum supervisors in the English Language Department in accordance with the academic qualification and teaching experience.

\section{Significance}

1. Addressing an important subject, i.e. practicum supervision, specifically the necessary characteristics of the English Language Department supervisors who play an important role in the development of the teacher education program. They monitor and upgrade the psychological, professional and application elements in student teachers.

2. Making a list of the necessary characteristics of the practicum supervisors in the English Language Department that can be utilized to develop and enhance their performance.

3. Opening the door for further studies that deal with other factors linked to the practicum phase to develop a program of supervision development and assessment of EFL supervisors.

\section{Limitations}

The study is limited to the perspective of practicum supervisors from the English Language Department at the female College of Education, King Abdul-Aziz University. It was conducted during the second semester of the Academic Year 2014, focusing on the personal, professional, language skills, and evaluation characteristics.

\section{Study Terms}

\subsection{Practicum}

According to Abdullah [11], "it is different activities which the student teacher learns about all aspects of practical education gradually to begin with watching and then proceed to load the duties performed by the teacher to ultimately reach the full proper practice". This is later stressed by other scholars who postulated that the practicum plays a major role in the teaching preparation program. During this period, which is usually one semester of continuous participation in the school life of teaching experience, the student teacher is given the opportunity to apply theory into practice and the supervision of a cooperative teacher and an assigned university supervisor. [1][2][3][4][5]

\subsection{Supervision}

AlDweik, et al. [12] defined supervision as "the process of democratic leadership in a cooperative organization that is concerned with the educational position, including its elements of curricula, means, methods, environment, and a teacher and student. It aims to study and assess the factors affecting the situation in order to achieve the objectives of education".

\subsection{Supervisor}

A specialist who supervises the student teachers during the period of practical education in schools has been identified for them. S/he follows the student teachers in terms of their attendance in schools and holds guiding meetings with them before and after scheduled visits to their classrooms. S/he also evaluates student teachers using a guided checklist prepared for that purpose by the program specialists at the university office of practical education. According to Gujjar et.al [4], her/his role is to serve as a resource person, an advisor, a general morale booster, an interpreter of feedback, and an assessor.

\subsection{The Characteristics}

They constitute the features or personal, professional, sociable and linguistic qualities that are required in the supervisor of EFL practicum.

\section{Review of the Literature}

Numerous Arab and non-Arab studies concerning the preparation of teachers in English language, practical education, and the supervising the process, in general, and their required characteristics, in particular, have been explored. For example, Waite [8] aimed to examine the understanding of new supervisors of the supervision. He 
applied a questionnaire to (110) postgraduate students in the supervision subject. He concluded that the supervisors must have the characteristics that focus on four areas: skills, expertise, knowledge, and attitude.

Simmons [10] inspected the professional background of three university supervisors, their vision for the supervision and the objectives of the teaching of student teachers, the author used cognitive maps and interviews. The study reaffirmed the importance of the presence of the personal characteristics, the satisfaction for the job and the desire to continue as well as the experience and education of supervisors of practical Education.

Soliday and Anderson [9] conducted a study attempting to verify the procedures adopted by the teacher training institutes for the assessment of the supervisors. The authors used a questionnaire applied to (49) institute directors. They concluded that personal characteristics and teaching should be considered.

Al-sherbeiny [13]carried out a study to evaluate the supervision of the practical education in the educational colleges. The sample of the study comprised (25) supervisors using card note and personal interviews. The results showed the lack of interest of the supervisors to many sides in the cases and methods of supervision.

Zheng and Webb[14] attempted to examine the effectiveness of a suggested model for student teacher supervision that made a shift in supervision responsibilities from the supervisors to qualified classroom teachers. Using a survey, the authors sought to find out respondents' perspectives regarding the qualifications of university faculty and cooperating teachers to assess and evaluate student teacher performance. The sample consisted of 18 of Kennesaw State University faculty, and 58 out of the 114 cooperating teachers. It was found out that cooperative teachers preferred the already used model than the new suggested one. University supervisors also preferred the same model as cooperative teachers. Both groups saw that the university supervisors were more qualified to evaluate and grade student teachers. Furthermore, they indicated that the best model is the one that combines both models; the old and the suggested ones.

Elsweedy [7] conducted a study to identify the role of practical education's supervisor using tasks to be exercised. He applied a questionnaire to (30) male and female supervisors and (240) student teachers from the seventh academic level. The results showed the lack of the attention of the supervisors in working to raise the professional and practical competence of the student teachers and to the means and methods that have the effect of supervision.

\section{Methodology and Procedures}

\subsection{Sample}

The sample of the study covers all supervisors at the practical education section of the English Language Department and (20) female supervisors, representing all faculty members of the College of Education for Girls, King Abdulaziz University. Table 1 shows the distribution of the sample by academic qualification and years of experience.

\subsection{Tools}

The study utilized a questionnaire that includes a list of the necessary characteristics of the supervisors at the practical education section of the English Language Department identified by the author through the information provided in the review of literature, in addition to the author's experiences and concerns in the field.

It used items from the list found in Schiff [15] which identified competencies and indicators for English supervisors. The list was developed by supervisors and student teachers to help educators demonstrate these competencies in their work. It contained the initial database, including academic qualification and years of experience. It also identified four domains: the personal and administrative characteristics that include (6) items, professional characteristics which include (21) items, language skills which include (18) items, and finally, the evaluation which includes (7) items.

\subsubsection{Validity of the Questionnaire}

The questionnaire in its primary form has been introduced to a number of professors at the Departments of Education and Psychology at the College of Education for Girls, Jeddah and King Abdul Aziz Universities in Jeddah with a view to reviewing the initial form of the list of the characteristics.

The author conducted the necessary adjustments considering the suggestions of the arbitrators.

\subsubsection{Reliability of the Questionnaire}

The questionnaire was calculated using (Cronbach's Alpha) resulting in a reliability coefficient of $(0.923)$. It is a high value and indicates the reliability of the tool.

Table 1. The distribution of the sample research academic qualification and years of experience

\begin{tabular}{|c|c|c|c|c|c|}
\hline Academic qualification & $\mathrm{N}$ & $\%$ & Years of experience & $\mathrm{N}$ & $\%$ \\
\hline Bachelor & 6 & 30 & from 1 to 5 years & 3 & 15 \\
\hline Master & 7 & 35 & from 6 to 10 years & 6 & 30 \\
\hline Doctorate & 7 & 35 & more than 10 years & 11 & 55 \\
\hline Total & 20 & 100 & Total & 20 & 100 \\
\hline
\end{tabular}




\subsection{Statistical Treatment}

The statistical methods represented in:

1. Frequencies, percentages, and means for all expressions of the questionnaire.

2. One way ANOVA to determine the significance of the differences between supervisors of practical education in the English Language Department depending on academic qualification and years of experience.

3. Scheffé test to determine the differences in the averages of the respondents' responses.

\section{Results and Discussion}

After applying the study tool by using frequencies and percentages, the means were calculated applying variance analysis and Scheffé test to the study sample. Tables 2-8 show the results:

Table 2 shows that the items that achieved the high rates are (strongly agree, agree) respectively items No. $(5,1)$ : $(35 \%-65 \%)$ the average of each item is (4.65). The item (No. 2): $(40 \%-60 \%)$ the average is $(4.60)$. The item (No. 3$)$ : $(40 \%-50 \%)$ the average is $(4.10)$. The item No. (6): $(25 \%$ strongly agree $-20 \%$ agree - $15 \%$ nEUTRAL $-35 \%$ disagree - $5 \%$ strongly disagree) the average is (2.95). Thus, the personal characteristics and administrative No. $(5,4,3,2,1)$ is the most important characteristics from the point of view of the supervisors at the practical education section of the English language. The item No. (6) is at least characteristics of importance.

Table 2. Frequencies, percentages, and means to the responses of the supervisors for the domain of the personal characteristics of the personnel

\begin{tabular}{|c|c|c|c|c|c|c|c|c|c|c|c|c|}
\hline \multirow[t]{2}{*}{ No. } & \multirow[t]{2}{*}{ Item } & \multicolumn{2}{|c|}{$\begin{array}{l}\text { Strongly } \\
\text { Agree }\end{array}$} & \multicolumn{2}{|c|}{ Agree } & \multicolumn{2}{|c|}{ Neutral } & \multicolumn{2}{|c|}{ Disagree } & \multicolumn{2}{|c|}{$\begin{array}{l}\text { Strongly } \\
\text { disagree }\end{array}$} & \multirow[t]{2}{*}{ Means } \\
\hline & & $\mathrm{N}$ & $\%$ & $\mathrm{~N}$ & $\%$ & $\mathrm{~N}$ & $\%$ & $\mathrm{~N}$ & $\%$ & $\mathrm{~N}$ & $\%$ & \\
\hline 1 & $\begin{array}{l}\text { The ability to innovate and innovation in } \\
\text { her missions }\end{array}$ & 13 & 65 & 7 & 35 & - & - & - & - & - & - & 4.65 \\
\hline 2 & $\begin{array}{l}\text { Establish a friendly relationship with the } \\
\text { student teachers }\end{array}$ & 12 & 60 & 8 & 40 & - & - & - & - & - & - & 4.60 \\
\hline 3 & $\begin{array}{l}\text { Establish a friendly relation with others } \\
\text { (management \& teachers) }\end{array}$ & 10 & 50 & 8 & 40 & 2 & 10 & - & - & - & - & 4.10 \\
\hline 4 & $\begin{array}{l}\text { Establish a friendly relationship with the } \\
\text { supervisors of the practical education } \\
\text { office at the college }\end{array}$ & 7 & 35 & 10 & 50 & 3 & 15 & - & - & - & - & 4.20 \\
\hline 5 & Knowledge of the school systems & 13 & 65 & 7 & 35 & - & - & - & - & - & - & 4.65 \\
\hline 6 & $\begin{array}{l}\text { Establish a good relationship with the } \\
\text { schoolgirls in the school where they are } \\
\text { trained. }\end{array}$ & 5 & 25 & 4 & 20 & 3 & 15 & 7 & 35 & 1 & 5 & 2.95 \\
\hline
\end{tabular}

Table 3. Frequencies, percentages, and means to the answers of the supervisors for the area of professional characteristics

\begin{tabular}{|c|c|c|c|c|c|c|c|c|c|c|c|c|}
\hline \multirow[t]{2}{*}{ No. } & \multirow[t]{2}{*}{ Item } & \multicolumn{2}{|c|}{$\begin{array}{l}\text { Strongly } \\
\text { Agree }\end{array}$} & \multicolumn{2}{|c|}{ Agree } & \multicolumn{2}{|c|}{ Neutral } & \multicolumn{2}{|c|}{ Disagree } & \multicolumn{2}{|c|}{$\begin{array}{l}\text { Strongly } \\
\text { disagree }\end{array}$} & \multirow[t]{2}{*}{ Means } \\
\hline & & $\mathrm{N}$ & $\%$ & $\mathrm{~N}$ & $\%$ & $\mathrm{~N}$ & $\%$ & $\mathrm{~N}$ & $\%$ & $\mathrm{~N}$ & $\%$ & \\
\hline 1 & $\begin{array}{l}\text { Knowledge of the concept of practical } \\
\text { education and its importance and objectives }\end{array}$ & 17 & 85 & 2 & 10 & 1 & 5 & - & - & - & - & 4.80 \\
\hline 2 & $\begin{array}{l}\text { Interest in holding guidelines meetings for } \\
\text { female student teachers }\end{array}$ & 16 & 80 & 4 & 20 & - & - & - & - & - & - & 4.80 \\
\hline 3 & $\begin{array}{l}\text { Knowledge of the objectives of the stage of } \\
\text { the study (preparatory, secondary) }\end{array}$ & 16 & 80 & 4 & 20 & - & - & - & - & - & - & 4.80 \\
\hline 4 & $\begin{array}{l}\text { Knowledge of the objectives of the English } \\
\text { language course }\end{array}$ & 17 & 85 & 3 & 15 & - & - & - & - & - & - & 4.85 \\
\hline 5 & School attendance and Commitment in dates & 13 & 65 & 7 & 35 & - & - & - & - & - & - & 4.65 \\
\hline 6 & $\begin{array}{c}\text { Knowledge of school girls' growth } \\
\text { characteristics in the stage } \\
\text { where they are taught }\end{array}$ & 11 & 55 & 8 & 40 & 1 & 5 & - & - & - & - & 4.35 \\
\hline 7 & Knowledge of theories of education & 7 & 35 & 12 & 60 & 1 & 5 & - & - & - & - & 4.30 \\
\hline 8 & How to prepare the lessons & 14 & 70 & 6 & 30 & - & - & - & - & - & - & 4.70 \\
\hline 9 & Knowing the types of educational means & 14 & 70 & 6 & 30 & - & - & - & - & - & - & 4.70 \\
\hline 10 & $\begin{array}{l}\text { Learn how to use the means } \\
\text { and its objectives. }\end{array}$ & 14 & 70 & 6 & 30 & - & - & - & - & - & - & 4.70 \\
\hline 11 & $\begin{array}{l}\text { Knowledge of the methods of teaching } \\
\text { English language }\end{array}$ & 1 & 80 & 3 & 15 & - & - & 1 & 5 & - & - & 4.70 \\
\hline 12 & Learn how to manage the class & 10 & 50 & 8 & 40 & 2 & 10 & - & - & - & - & 440 \\
\hline 13 & Respecting the rules in the class & 11 & 55 & 8 & 40 & 1 & 5 & - & - & - & - & 4.50 \\
\hline
\end{tabular}




\begin{tabular}{|c|c|c|c|c|c|c|c|c|c|c|c|c|}
\hline 14 & $\begin{array}{c}\text { Knowledge of the good utilization } \\
\text { of the blackboard }\end{array}$ & 13 & 65 & 7 & 35 & - & - & - & - & - & - & 4.65 \\
\hline 15 & $\begin{array}{c}\text { Awareness of the problems of the English } \\
\text { language curriculum }\end{array}$ & 14 & 70 & 6 & 30 & - & - & - & - & - & - & 4.70 \\
\hline 16 & $\begin{array}{c}\text { The ability to manage classroom } \\
\text { activities effectively }\end{array}$ & 10 & 50 & 7 & 35 & 3 & 15 & - & - & - & - & 4.20 \\
\hline 17 & $\begin{array}{c}\text { Knowledge of the appropriate references } \\
\text { that benefited student teachers }\end{array}$ & 11 & 55 & 8 & 40 & - & - & - & - & - & - & 4.40 \\
\hline 18 & $\begin{array}{c}\text { The ability to confront problems and } \\
\text { emergency situations }\end{array}$ & 13 & 65 & 7 & 35 & - & - & - & - & - & - & 4.65 \\
\hline 19 & $\begin{array}{c}\text { Knowledge of the methods of dealing with } \\
\text { low achievers }\end{array}$ & 7 & 35 & 12 & 40 & 1 & 5 & - & - & - & - & 4.30 \\
\hline 20 & The ability to teach effectively & 18 & 90 & 2 & 35 & - & - & - & - & - & - & 4.90 \\
\hline 21 & $\begin{array}{c}\text { Knowledge of methods and strategies for } \\
\text { effective supervision }\end{array}$ & 16 & 80 & 4 & 60 & - & - & - & - & - & - & 4.80 \\
\hline
\end{tabular}

Table 4. Frequencies, percentages, and means of the answers of the supervisors in the field of linguistic skills

\begin{tabular}{|c|c|c|c|c|c|c|c|c|c|c|c|c|}
\hline \multirow[t]{2}{*}{ No. } & \multirow[t]{2}{*}{ Item } & \multicolumn{2}{|c|}{ Strongly Agree } & \multicolumn{2}{|c|}{ Agree } & \multicolumn{2}{|c|}{ Neutral } & \multicolumn{2}{|c|}{ Disagree } & \multicolumn{2}{|c|}{$\begin{array}{l}\text { Strongly } \\
\text { disagree }\end{array}$} & \multirow{2}{*}{$\begin{array}{c}\text { Means } \\
\mathrm{N}\end{array}$} \\
\hline & & $\mathrm{N}$ & $\%$ & $\mathrm{~N}$ & $\%$ & $\mathrm{~N}$ & $\%$ & & & $\mathrm{~N}$ & $\%$ & \\
\hline 1 & Presentation of vocabulary & 17 & 85 & 3 & 15 & - & - & - & - & - & - & 4.85 \\
\hline 2 & Training on vocabulary & 16 & 80 & 3 & 15 & - & - & 1 & 5 & - & - & 4.85 \\
\hline 3 & Teaching of basic reading & 16 & 80 & 4 & 20 & - & - & - & - & - & - & 4.70 \\
\hline 4 & Reading presentation & 15 & 75 & 5 & 25 & - & - & - & - & - & - & 4.80 \\
\hline 5 & Reading activities & 15 & 75 & 5 & 25 & - & - & - & - & - & - & 4.75 \\
\hline 6 & Listening activities & 15 & 75 & 5 & 25 & - & - & - & - & - & - & 4.75 \\
\hline 7 & Communication activities & 16 & 80 & 4 & 20 & - & - & - & - & - & - & 4.75 \\
\hline 8 & Role Play & 10 & 50 & 9 & 45 & 1 & 5 & - & - & - & - & 4.80 \\
\hline 9 & The presentation of writing activities & 16 & 80 & 4 & 20 & - & - & - & - & - & - & 4.45 \\
\hline 10 & $\begin{array}{l}\text { The presentation of } \\
\text { the grammatical structures }\end{array}$ & 16 & 80 & 4 & 20 & - & - & - & - & - & - & 4.80 \\
\hline 11 & Exercise on grammatical structures & 17 & 85 & 3 & 15 & - & - & - & - & - & - & 4.80 \\
\hline 12 & Teaching words (pronunciation) & 17 & 85 & 3 & 15 & - & - & - & - & - & - & 4.85 \\
\hline 13 & Teaching writing & 17 & 85 & 3 & 15 & - & - & - & - & - & - & 4.85 \\
\hline 14 & The art of formulating questions & 18 & 90 & 3 & 10 & - & - & - & - & - & - & 4.85 \\
\hline 15 & Organize bilateral work and teamwork & 12 & 60 & 8 & 40 & - & - & - & - & - & - & 4.90 \\
\hline 16 & Correct mistakes & 17 & 85 & 3 & 15 & - & - & - & - & - & - & 4.60 \\
\hline 17 & Development of a lesson plan & 17 & 85 & 3 & 15 & - & - & - & - & - & - & 4.85 \\
\hline 18 & The use of English in the classroom & 16 & 80 & 4 & 20 & - & - & - & - & - & - & 4.80 \\
\hline
\end{tabular}

Table 3 indicates that the items that achieved the high rates are the (strongly agree, I agree) as follows: item No. (20): $(90 \%-10 \%)$ the average is $(4.90 /)$, item (No. 4): $(85 \%$ $15 \%)$ the average is $(4.85)$, item No. (1): $(80 \%-20 \%)$ the average is $(4.80)$, item No. $(8,9,10,15):(70 \%-30 \%)$ the average (4.70), phrase No. (11): $(80 \%-15 \%)$ the average is (4.70), and item $(5,14,18):(65 \%-35 \%)$ the average is (4.50), item No. (12): $(50 \%-40 \%)$ the average (4.40), item No. (17): $(55 \%-40 \%)$ the average is $(4.35)$, ferries No. (7, $19):(35 \%-60 \%)$ the average is $(4.30)$, item (No. 16$):(50 \%-$ $35 \%)$ the average is (4.20). Thus, all the professional characteristics are the most important from the point of view of the supervisors.

Table 4 shows that the items that achieved high rates are (strongly agree, I agree) as follows:
Item No. (15): $(60 \%-40 \%)$ the average is $(4.90 /)$, item No. $(1,12,13,17):(85 \%-15 \%)$ the average is $(4.85)$, item No. (14): (90\% - 10\%) the average is (4.85), the item (No. 2): $(80 \%-15 \%)$ the average is $(4.85)$, the item No. (1): $(80 \%$ $15 \%)$ : The average is $(4.85)$, the item No. (1): $(85 \%-15 \%)$ the average is $(4.80)$, item No. $(10,18):(80 \%-20 \%)$ the average is (4.80), the item (No. 4$):(75 \%-25 \%)$ the average is (4.80), the item No. (7): $(80 \%-20 \%)$ the average is (4.75), item No. $(5,6):(75 \%-25 \%)$ the average is $(4.75)$, the item No. (3): $(80 \%-20 \%)$ the average is $(4.70)$, the item (No. 16$)$ : $(85 \%-15 \%)$ the average is $(4.60)$, the item No. (9): $(80 \%$ $20 \%$ ) the average is (4.45). Thus, all the characteristics of the linguistic skills are the most important from the point of view of the supervisors.

Table 5 indicates that the items that achieved high rates are 
(strongly agree, agree) as follows:

The items No. (1): $(90 \%-10 \%)$ the average is (4.90), items No. $(4,5): 75 \%-25 \%)$ the average is $(4.75)$, items No. (3): $(70 \%-20 \%)$ the average is $(4.60)$, items (No. 2$):(60 \%$ $40 \%)$ the average is $(4.60)$, items No. $(6,7):(50 \%-40 \%)$ the average is (4.40). Thus, all the characteristics of the Evaluation are the most important from the point of view of the supervisors.

The previous findings show that the necessary characteristics of the supervisors at the practical education section of the English language Department are highly important from the point of view of the sample members. As it has been proved by the high proportions, the author considers that the presence of these characteristics of the supervisor of practical education might lead to increasing the performance level of student teachers in the English Language Department through directing them proper guidance in aspects (personal and professional, linguistic and evaluation). These characteristics are required by the supervisors in order to perform their supervisory role, given that there are complaints about the poor performance of the student teachers in the English Language Department.

The results of the current study agree with Waite [8] who stressed the importance of the skills, expertise, and knowledge of the supervisors of practical education and Simmons [10] who pointed to the importance of personal characteristics, job satisfaction, and the desire to maintain education of the supervisors of practical education. Solliday and Anderson[9] also referred to the considerations to be taken in the evaluation of the supervisors, including personal characteristics and the ability to teach.

However, these results differ from those of El-Sherbini[13] who showed that many personal qualities and professional and language skills do not impair the attention of most supervisors.

Table 6 shows that there were no statistical differences among the three groups in the necessary characteristics of the supervisors at the practical education section of the English Language Department in accordance with the school qualification, where the F-Results reached $(0.346,0.068$, $0.401,0.456)$.

Table 5. Frequencies and percentages and Means to the answers of the supervisors for the Evaluation

\begin{tabular}{|c|c|c|c|c|c|c|c|c|c|c|c|c|}
\hline \multirow[t]{2}{*}{ No. } & \multirow[t]{2}{*}{ Item } & \multicolumn{2}{|c|}{$\begin{array}{l}\text { Strongly } \\
\text { Agree }\end{array}$} & \multicolumn{2}{|c|}{ Agree } & \multicolumn{2}{|c|}{ Neutral } & \multicolumn{2}{|c|}{ Disagree } & \multicolumn{2}{|c|}{$\begin{array}{l}\text { Strongly } \\
\text { disagree }\end{array}$} & \multirow{2}{*}{$\begin{array}{c}\text { Means } \\
\mathrm{N}\end{array}$} \\
\hline & & $\mathrm{N}$ & $\%$ & $\mathrm{~N}$ & $\%$ & $\mathrm{~N}$ & $\%$ & & & $\mathrm{~N}$ & $\%$ & \\
\hline 1 & Knowledge of the different ways the Evaluation & 18 & 90 & 2 & 10 & - & - & - & - & - & - & 4.90 \\
\hline 2 & $\begin{array}{l}\text { Promotion of self-evaluation } \\
\text { among student teachers }\end{array}$ & 12 & 60 & 8 & 40 & - & - & - & - & - & - & 4.60 \\
\hline 3 & Knowledge of advanced methods for evaluation & 14 & 70 & 4 & 20 & 2 & 10 & - & - & - & - & 4.60 \\
\hline 4 & $\begin{array}{l}\text { Knowledge of the foundations of evaluating } \\
\text { students and method of application. }\end{array}$ & 15 & 75 & 5 & 25 & - & - & - & - & - & - & 4.75 \\
\hline 5 & $\begin{array}{l}\text { Know the basics of evaluation } \\
\text { in practical education. }\end{array}$ & 15 & 75 & 5 & 25 & - & - & - & - & - & - & 4.75 \\
\hline 6 & $\begin{array}{c}\text { Contribute to submitting proposals for the } \\
\text { development of the program }\end{array}$ & 10 & 50 & 8 & 40 & 2 & 10 & - & - & - & - & 4.40 \\
\hline 7 & The use of effective feedback & 10 & 50 & 8 & 40 & 2 & 10 & - & - & - & - & 4.40 \\
\hline
\end{tabular}

Table 6. The results of (ANOVA) according to variable academic qualification (Doctorate, master, and bachelor) for the supervisors of practical education section of the English language Department

\begin{tabular}{|c|c|c|c|c|c|c|}
\hline Domains & Source & Df & Sum. of squares & Means of squares & $\mathrm{F}$ & Sig \\
\hline \multirow{3}{*}{$\begin{array}{l}\text { The personal and the } \\
\text { Administrative } \\
\text { characteristics }\end{array}$} & Between groups & 2 & 11.431 & 5.715 & \multirow{3}{*}{0.346} & \multirow{3}{*}{ Not sig } \\
\hline & Within groups & 17 & 281.119 & 16.536 & & \\
\hline & Total & 19 & 292.550 & & & \\
\hline \multirow{3}{*}{$\begin{array}{l}\text { The professional } \\
\text { characteristics }\end{array}$} & Between groups & 2 & 6.074 & 3.037 & \multirow{3}{*}{0.068} & \multirow{3}{*}{ Not sig } \\
\hline & Within groups & 17 & 754.476 & 44.381 & & \\
\hline & Total & 19 & 760.550 & & & \\
\hline \multirow{3}{*}{ Language skills } & Between groups & 2 & 28.571 & 14.286 & \multirow{3}{*}{0.401} & \multirow{3}{*}{ Not sig } \\
\hline & Within groups & 17 & 605.429 & 35.603 & & \\
\hline & Total & 19 & 634.000 & & & \\
\hline \multirow{3}{*}{ The evaluation } & Between groups & 2 & 6.252 & 3.126 & \multirow{3}{*}{0.456} & \multirow{3}{*}{ Not sig } \\
\hline & Within groups & 17 & 116.548 & 6.856 & & \\
\hline & Total & 9 & 122.800 & & & \\
\hline
\end{tabular}


Table 7. the results of (ANOVA) according to variable experiences (Doctorate, master, and bachelor) for the supervisors of practical education section of the English language Department

\begin{tabular}{|c|c|c|c|c|c|c|}
\hline Domains & Source & df & Sum. of squares & Means of squares & $\mathrm{F}$ & Sig \\
\hline \multirow{3}{*}{$\begin{array}{l}\text { The personal } \\
\text { characteristics of the } \\
\text { administrative }\end{array}$} & Among the groups & 2 & 6.368 & 3,184 & \multirow{3}{*}{0.89} & \multirow{3}{*}{ Not Sig } \\
\hline & Within groups & 17 & 286.182 & 16.834 & & \\
\hline & The total & 19 & 292.550 & & & \\
\hline \multirow{3}{*}{$\begin{array}{l}\text { The professional } \\
\text { characteristics }\end{array}$} & Among the groups & 2 & 40.914 & 20.457 & \multirow{3}{*}{0.483} & \multirow{3}{*}{ Not Sig } \\
\hline & Within groups & 17 & 719.636 & 42.332 & & \\
\hline & The total & 19 & 760.550 & & & \\
\hline \multirow{3}{*}{ Language skills } & Among the groups & 2 & 53.591 & 26.795 & \multirow{3}{*}{0.785} & \multirow{3}{*}{ Not Sig } \\
\hline & Within groups & 17 & 850.409 & 34.42 & & \\
\hline & The total & 19 & 634.00 U.S. & & & \\
\hline \multirow{2}{*}{ The evolution } & Among the groups & 2 & 0.618 & 0.309 & \multirow{2}{*}{0.043} & \multirow{2}{*}{ Not Sig } \\
\hline & The total & 19 & 122.800 & & & \\
\hline
\end{tabular}

Table 8. results of testing the average of expertise in the domain of Language Skills

\begin{tabular}{|c|c|c|c|}
\hline Domain & One to 5 years & From 5 to 10 years & over 10 years \\
\hline \multirow{3}{*}{$\begin{array}{c}\text { Language } \\
\text { skills }\end{array}$} & 5.17 & 5.17 & 3.24 \\
\cline { 2 - 4 } & 3.24 & - & 1.92 \\
\cline { 2 - 4 } & & 1.92 & - \\
\hline
\end{tabular}

Table No. 7 shows that there are not statistically significant differences among the three groups (from 1 to 5 years, from 6 to 10 years, more than 10 years) in some of the necessary characteristics of the supervisors at the practical education section of the English language, in the personal characteristics of the administrative, professional characteristics, and evaluation), where the F-Results (1.89, $0.483,0.43)$. It also indicates that there are statistically significant differences at the level of 0.05 among the three groups in the particularities of the linguistic skills as the F-Results (0.785). This means that the opinion of the participants in the linguistic skills is different depending on teaching experience. To identify the differences averages, Scheffé test was adopted. Table 8 shows statistically significant differences between the averages of the degrees of the second and the third groups in favor of the second group, and among the first group and the second in favor of the first group. The first and second groups are superior as a result of the interest in linguistic skills necessary for the supervisors at the practical education section of the English Language Department.

\section{Recommendations}

1. Emphasize the importance of the necessary characteristics of the female supervisors and motivate them to take advantage of these characteristics in the supervision process

2. Prepare a guide for the supervisors at the practical education section of the English Language Department that includes (aims of the education process, the necessary characteristics and role of female supervisors, the concept and importance of supervision, and the methods of evaluation in practical education).

3. Training courses contribute to raising the efficiency of supervisors at the practical education section of the English language.

4. The principals in the Office of practical education should hold meetings continuously and systematically to discuss issues relating to practical education and supervision and relevant problems.

5. Conduct studies on other aspects of the supervision of practical education to identify the required characteristics and the knowledge of the methods of supervision and application.

6. Conduct a similar study to determine the characteristics needed for supervisors with regard to student teachers.

\section{Questionnaire of the Opinions of Supervisors of Practicum in the Department of English at the Necessary Characteristics for them}

Kindly read each statement and check $(\checkmark)$ in the box that shows your opinion (strongly agree, agree, neutral, disagree, and strongly disagree).

Note that your answer will be used for the purposes of scientific research only.

Thank you for your cooperation 


\section{Academic Qualification}
[1] Bachelor
(1) master
(7) Doctor

The number of years of experience:
, from 1 to 5 years
7. from 6 to 10 years
๑7 over 10 years

\begin{tabular}{|c|c|c|c|c|c|c|}
\hline item No. & Item & $\begin{array}{c}\text { Strongly } \\
\text { Agree }\end{array}$ & Agree & Neutral & disagree & $\begin{array}{l}\text { Strongly } \\
\text { disagree }\end{array}$ \\
\hline First & The personal and the Administrative characteristics & & & & & \\
\hline 1 & The ability to innovate and innovation in her missions & & & & & \\
\hline 2 & Establish a friendly relationship with the student teachers & & & & & \\
\hline 3 & Establish a friendly relation with others (management \& teachers) & & & & & \\
\hline 4 & $\begin{array}{l}\text { Establish a friendly relationship with the supervisors of the } \\
\text { practical education office in college }\end{array}$ & & & & & \\
\hline 5 & Knowledge of the school systems & & & & & \\
\hline 6 & $\begin{array}{l}\text { Establish a good relationship with the schoolgirls in the school } \\
\text { where they are trained }\end{array}$ & & & & & \\
\hline Second & The professional characteristics & & & & & \\
\hline 1 & $\begin{array}{l}\text { Knowledge of the concept, importance, } \\
\text { and objectives of practical education }\end{array}$ & & & & & \\
\hline 2 & interest in holding guidelines meetings for female student teachers & & & & & \\
\hline 3 & $\begin{array}{l}\text { Knowledge of the objectives of the stage of the study } \\
\text { (preparatory \& secondary) }\end{array}$ & & & & & \\
\hline 4 & Knowledge of the objectives of the English language course & & & & & \\
\hline 5 & School attendance and Commitment in dates & & & & & \\
\hline 6 & $\begin{array}{l}\text { Knowledge of schoolgirls growth characteristics } \\
\text { in the stage they are enrolled }\end{array}$ & & & & & \\
\hline 7 & Knowledge of theories of education & & & & & \\
\hline 8 & How to prepare the Lessons & & & & & \\
\hline 9 & Knowing the types of educational means & & & & & \\
\hline 10 & Learn how to use the means and its objectives & & & & & \\
\hline 11 & Knowledge about the methods of teaching English language & & & & & \\
\hline 12 & Learn how to manage the class & & & & & \\
\hline 13 & Respecting the rules in the class & & & & & \\
\hline 14 & Knowledge of the good utilization of the blackboard & & & & & \\
\hline 15 & Awareness of the problems of the English language curriculum & & & & & \\
\hline 16 & The ability to manage classroom activities effectively & & & & & \\
\hline 17 & $\begin{array}{l}\text { Knowledge of appropriate references } \\
\text { which benefited student teachers }\end{array}$ & & & & & \\
\hline 18 & The ability to confront the problems and emergency situations & & & & & \\
\hline 19 & Knowledge of the methods of dealing with low achievers & & & & & \\
\hline 20 & The ability to teach effectively. & & & & & \\
\hline 21 & Knowledge of methods and strategies for effective supervision & & & & & \\
\hline Third. & Language skills & & & & & \\
\hline 1 & The vocabulary & & & & & \\
\hline 2 & The training of the vocabulary & & & & & \\
\hline 3 & The teaching of basic reading & & & & & \\
\hline 4 & Reading presentation & & & & & \\
\hline 5 & Reading activities & & & & & \\
\hline 6 & The activities of the listening & & & & & \\
\hline 7 & Communication activities & & & & & \\
\hline 8 & Role Play & & & & & \\
\hline
\end{tabular}




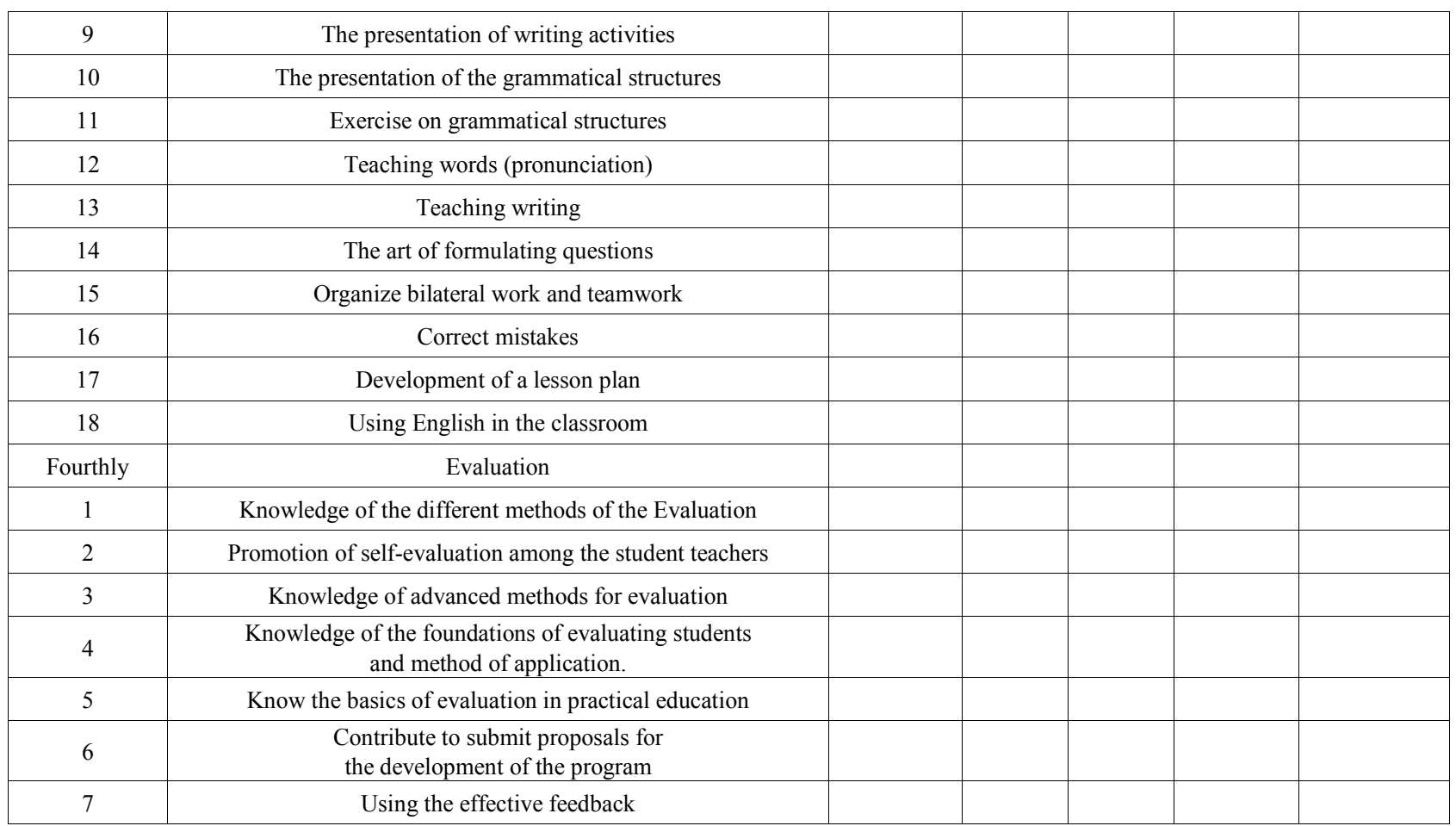

\section{REFERENCES}

[1] Beck C, Kosnik C. Professor and the practicum-involvement of university faculty in pre-service practicum supervision. J. Teacher Edu. 2002; 53(1): 6-19.

[2] Tuli F. Practicum experience in teacher education. Ethiopian J. Edu. and Sci. 2009; 5(1): 107 - 116.

[3] Smith K. Assessing the practicum in teacher education - Do we want candidates and mentors to agree? Studies in Edu. Evaluation. 2010; 36 (1): 36-41

[4] Gujjar A, Ramzan M, Bajwa M. An evaluation of teaching practice: practicum. Pakistan J. Commerce and Soc. Sci. 2011; 5(2): 302-318

[5] Al-Sohbani, Y. Prospective EFL teachers' perceptions of the teaching practice experience at AUST. Arab World English J. 2012; 3(4): 195-213.

[6] Kathiri, H. Trainee student's role and responsibilities in the field of education from his point of view and the view of the college supervisor. king Saud University magazine. 1996; IX: 185-221.

[7] Elsweedy, W. The role of supervisor of the practical education and comparative study of the perceptions of the supervisors and student teachers about this role. Education. 1994; 109: 49-125.

[8] Waite D. Novice supervisors' understanding of supervision. Paper presented at: Proceedings of the Annual Meeting of the
American Educational Research Association, Georgia; 1993. Available from ERIC Document Reproduction Service ED360734.

[9] Solliday M A, Anderson K. The University supervisors. What place in academe? Student Teac Supervisor Questionnaire. Paper presented at: Proceedings of Annual convention, Association of Teacher Educate, Georgia; 1977. Available from RIC Document Reproduction Service ED141321.

[10] Simmons J M. An exploration of the role perspectives and evaluative judgment criteria of three university student teacher supervisors; 1986. Available from ERIC Document Reproduction Service ED285855).

[11] Abdullah A S. The role of practical education in the preparation of teachers. I 2. Beirut: Dar Al-Fikr; 1979.

[12] AlDweik, Tayseer et al. Foundations of educational and school management, educational supervision. Amman: Dar Al-Fikr; 1997.

[13] Al-sherbeiny Z M. Evaluation of the supervision of process of education in the field of English language teaching [unpublished dissertation]. Ain-Shams University; 1974.

[14] Zheng B, Webb L. A new model of student teacher supervision: Perceptions of supervising teachers. Paper presented at: Proceedings of the Annual Meeting the Mid-South Educational Research Association, Georgia; 2000. Available from ERIC Document Reproduction Service ED447136.

[15] Schiff P M. Competencies and indicators for English supervisors. Paper presented at: Proceedings of the Annual Meeting of the Conference on English Education, Tennessee; 1977. Available from ERIC Document Reproduction Service ED13900010. 